\title{
SMART EDUCATIONAL TECHNOLOGY IN THE LEARNING PROCESS AT A RURAL VOCATIONAL TRAINING INSTITUTION - A CASE STUDY
}

\begin{abstract}
Judita KASPERIŪNIENÉ, Centre of Study Quality and Inovations, Department of Philosophy, Psychology and Vocational Education, Aleksandras Stulginskis University, Studentų g. 11, Akademija LT-53361, Kauno raj., Lithuania, judita.kasperiuniene@asu.lt (corresponding author)

Sigitas DAUKILAS, Centre of Cultural Communication and Education, Department of Philosophy, Psychology and Vocational Education, Aleksandras Stulginskis University, Universiteto g. 10, Akademija LT-53067, Kauno raj., Lithuania, sigitas.daukilas@asu.lt

Smart educational technology in the learning process at a vocational training institution directly correlates to the pedagogical and methodological preparation of teachers and their practical experience. The pedagogical preparation determines better learning outcomes, effective social and cultural expressions, and more qualitative guidance of the didactic process. In addition, teachers with the help of technology have the opportunity to draw attention to each student, help the learner to know himself and his or her field of professional expression. This case study examined the ability of vocational teachers to use various technologies in class. Study was conducted in five rural vocational training schools in Lithuania. Twenty five vocational teachers were interviewed using focus group interview format about their smart educational technology usage in teaching and contacting their students. Teachers were observed manipulating, transforming and allocating appropriate digital media, adapting teaching content and easily forming teaching-learning networks to achieve educational goals. Overall, the process described here showed that regardless of how long vocational teachers work at a rural school and what subjects they teach, mostly teachers communicated and collaborated through technologies with their students while presenting vocational teaching content. Finally, the technological competence of vocational teachers reflected the teacher's ability to carry out a certain vocational teaching process: the ability to perform technological operations, the skill to work with various materials, equipment and the mentoring capacity.
\end{abstract}

Keywords: case study, learning process, smart education technology, teachers' perspective, rural vocational training institution

\section{INTRODUCTION}

A vocational teacher uses different techniques which depends on the subject and context in which training takes place (Billett and Choy, 2013). Many VET methods are based on practice. In many cases the training is supported by monitoring and simulating specific work processes (Marchand, 2008); experimenting at a particular workplace (Shaidullina et al., 2014). Educational technologies encourage students to reflect and adapt what has been learned. Studies on technology-based learning show that the change in society and education affects the choice of learning theories and technologies. Learning theories and educational technologies are interconnected by invisible conceptual relationships; intertwined through the processing of information and the accumulation of knowledge.

Vocational schools are involved in innovation processes that affect all organizational components: curriculum, staffing, infrastructure. Teachers and students acquire new competences that create new teaching and learning perspectives (Hämäläinen and De Wever, 2013). In this context smart educational technology is not a new concept anymore. Over the last decades in vocational education and training (VET) institutions there have been major transformations: changes appeared in form, capacity, educational presentation, communication and collaboration with students and mentees. Pedagogical interpretations of how to use smart education technologies constructively faced growth (Stewart et. al, 2010).

Vocational knowledge development is significantly affected by vocational instruction (Deutscher and Winther, 2017). The vocational instruction approach as competence-based education emerged in Lithuania during vocational education and training reform and is still live today (Tütlys and Aarna, 2017). Our study covers ISCED 3 (upper secondary) and ISCED 4 (post-secondary non-tertiary) level vocational training institutions located in rural areas in Lithuania. Vocational upper secondary education (ISCED 3) in Lithuania is less common than in most European countries. Lithuania's gender gap in employment rates is relatively small. Besides that, tertiary-educated women earn 24 percentage less than tertiary-educated men and this influence motivation for learning and future labor activities (Education

Copyright (C) 2017 The Authors. Published by Aleksandras Stulginskis University. This is an open-access article distributed under the terms of the Creative Commons Attribution License (CC-BY 4.0), which permits unrestricted use, distribution, and reproduction in any medium, provided the original author and source are credited. 
at a Glance: OECD Indicators, 2016). In school year 2015/2016 vocational training institutions had more than 68 percent female teachers (Lithuanian education in numbers, 2016). The newest national data showed that only 15 percentage of young adults are expected to complete vocational upper secondary education. In other European countries this average is almost twice higher.

Rural vocational training in Lithuania fully or partly is delivered in these study fields: engineering; production; agriculture, forestry and fisheries; social services; transport services; environmental protection. Rural vocational study programmes are not popular in a country: for example school year 2014/2015 data showed that 472 Lithuanian students were trained as agriculture, forestry and fisheries specialists and 25 students as environment protection specialists (Lithuanian education in numbers, 2016).

Many vocational teachers prefer printed learning materials and oral lectures than online communication. Lithuanian education in numbers (2016) underlined that only 71 percent of vocational learners use computer and internet for the study purposes. The main silent argument against technology enhanced learning is the fear that technology will kill live educational contact (Keengwe and Bhargava, 2014).

Traditionally teacher-student contact in education setting occur when teacher and student physically meet and interact. In our days the alternative exist: teacher could virtually contact students through social media. Online teaching, mentoring, coaching or consulting is similar to traditional mentoring with one exception: technology becomes the primary mode of communication (Dawson, 2010).

This national context was taken into account researching technology application in the learning process at a rural vocational training institution. The main research questions were: i) what influences the smart educational technology application to teaching at a rural vocational training institution? ii) How teacher use social media for communication and collaboration with students during the learning process?

\section{METHODOLOGY}

The case study research design (Yin, 2013) was used to explore the process of technology usage in rural vocational training institution. Five vocational training schools from rural Lithuanian regions were observed. Five focus groups were conducted seeking to understand their smart technology application experiences and processes. All the focus groups were held at VET school premises. Typically, a focus group consisted of five teachers, age 29 to 55, teaching technologies, social sciences and agriculture subjects. Focus group discussions lasted from 55 till 95 minutes and were moderated by second author of the paper. A sample comprised 75 percent female. Group interviews were recorded and later transcribed verbatim.

Qualitative initial data coding and categorizing was done grouping focus group segments and summarizing each part (Corbin and Strauss, 1990). Later, mapping of categories was developed (Harry et al, 2005).

Research triangulation was maintained through a survey of the same research participants (Oliver-Hoyo and Allen, 2006). Participants were asked about smart technology applications (which application they used and how many materials do they provided online) and how they virtually communicated and collaborated with students.

Research participants were informed about the purpose of the research, methods applied. Conflicts of interest were avoided seeking to construct the homogenous focus group - only teachers who were not administrators or school decision makers took part in research. Research participants' information was anonymized and confidentiality maintained (Merriam, 1998).

The VET educational community, where research was done, was located in rural area of Lithuania. In the researched schools students could receive secondary education and carrier education. School community consisted of approximately 200-400 students and 20-30 teachers. Some VET teachers had qualification of teacher-supervisor or elder teacher. Other teachers come from production or agriculture sectors. VET school teachers constantly improved school curricular concerning the rural market needs and following educational requirements. Some schools were involved in EU mobility project activities. Almost all school teachers were loyal to their institution, staff migration was small. Many teachers teach few related subjects. The school community were dominated by female teachers.

It was found, that for Lithuanian rural vocational teachers it is still a challenge to communicate and collaborate with their students using internet technologies. This communication happens in informal settings. Findings summarize rural VET teachers' perspectives and this is only educators' voice.

\section{FINDINGS}

In a qualitative study three categories were constructed: self-motivation; innovative study methods; mastery in technology. These categories are interconnected, overlapped and dependent on each other. They form the circular explanation of the reasons for the use of educational technology in vocational training class (Figure 1).

In Figure 1, each category is marked with a rectangle. Dimensions of category are mapped inside the category. The links of category dimensions are marked with arrows. Direction of the arrow shows the technology usage in rural vocational training institution process flow. The Figure 1 could be read in two ways: i) starting from Self-motivation category and going down and left or ii) starting from Self-motivation and going counter clockwise left and down. This process cycle is not complete: additional motivation influences raising of new innovative study methods and selfmotivation activates the desire to dig into smart educational technologies. 


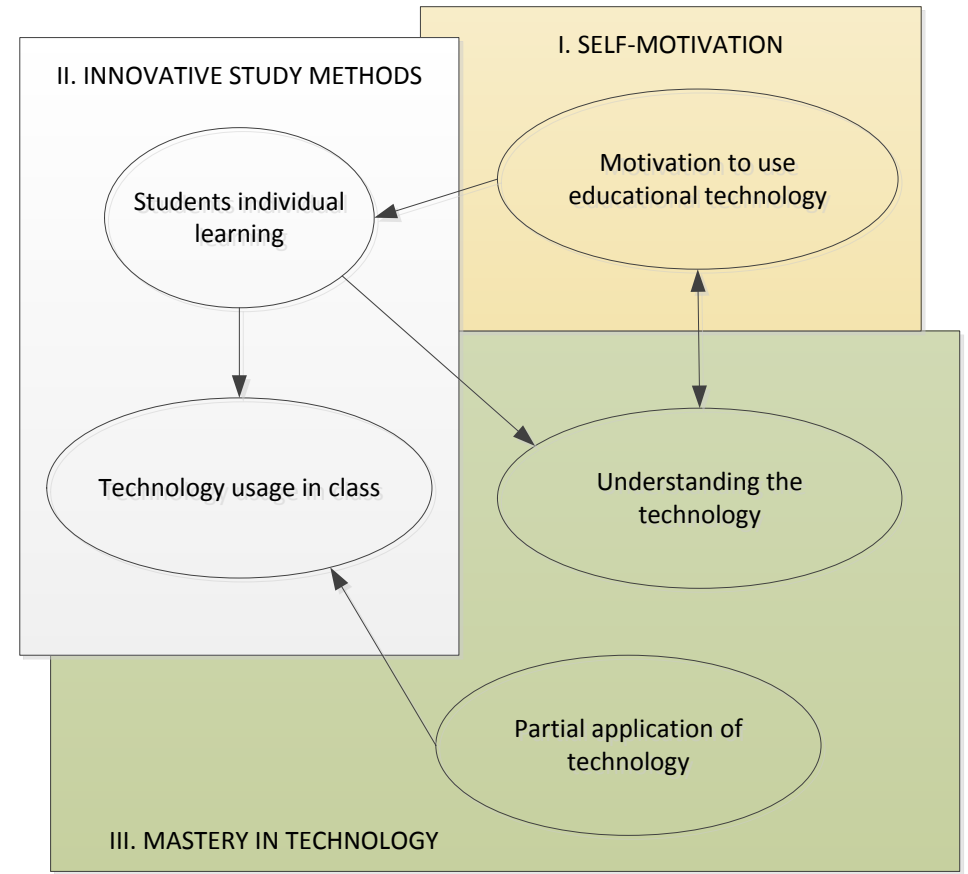

Figure 1. The causes of technology usage in rural vocational training institution (teachers' perspective)

Self-motivation (Block I) is explained as teachers' self-regulated intension to use new, innovative, smart educational solutions in class. This self-motivation has direct links with Mastery in technology (Block II) through Understanding the technology and vice versa. From the other side Motivation to use education technology influences how teachers chose vocational teaching and learning methods and is directly targeted Innovative study methods (Block III) and Students individual learning. Students' individual learning influences Technology usage in class which on Partial application of technology. Besides that Students individual learning is directly influenced Understanding the technology. This circular wave could turn both directions from the same starting point- Self-motivation; Mastery in technology; Innovative study methods or Self-motivation; Innovative study methods; Mastery in technology. This circular wave continues without stops.

The participants' quantitative survey showed that the majority of researched teachers communicated and collaborated with the students. More than 60 percent of informants' preferred physical communication in class. The intension of live communication is not depended on teaching subject: the same behavior was observed in teachers of agriculture, technologies and social sciences. Teachers who preferred physical communication varied in educational experience and professional proficiency (Table 1).

Table 1. VET teacher communication with students: tools and methods

\begin{tabular}{|l|c|c|c|c|c|}
\hline \multirow{2}{*}{ VET teachers communication with students } & \multicolumn{5}{|c|}{ Percent of teachers } \\
\cline { 2 - 6 } & Strongly disagree & Disagree & Neutral & Agree & Strongly agree \\
\hline Communicating only physically (in class) & 0,3 & 0,3 & 4,7 & 30,8 & $\mathbf{6 3 , 9}$ \\
\hline $\begin{array}{l}\text { Providing learning materials online (without } \\
\text { virtual discussions) }\end{array}$ & 8,9 & 19,9 & $\mathbf{3 7 , 1}$ & 25,5 & 8,6 \\
\hline $\begin{array}{l}\text { Creating positive emotional class environment } \\
\text { (physically and virtually) }\end{array}$ & 0 & 0,3 & 5,2 & 37,6 & $\mathbf{5 5 , 2}$ \\
\hline
\end{tabular}

In rural VET schools the tendency of weak students control was observed. 63,9 percent of informants preferred communication and collaboration with students in class without the technology. To post learning materials online was not very popular in VET teachers' community. 37,1 percent of teachers were neutral to that and 19,9 percent of informants disagreed. Besides these data, more than half of VET teachers (55,2 percent) strongly agreed with the idea physically and virtually communicate and collaborate with their students and created positive emotional class environment. It is important to mention that teachers, who do not recognize direct communication or do not like to create good emotional microclimate, were not observed.

Focus groups showed that live communication could be a solution for teacher - student collaboration in class. Believes and preunderstandings that forms negative attitudes towards the use of social media in the classroom were spread by mass media channels and found in personal conversations (Figure 2).

Although the technological tools are suitable not only for communication and collaboration in class, but also for the sharing the study material, research participants preferred making physical lectures. This decision was based on teachers' observations of learners multitasking, browsing the device and gaming, even listening to music during lectures or practical classes. Teachers observed, that their students check Facebook at school, read and comment on social media postings and 
even record lecture videos. Some teachers do not allow using smart phones during lectures while others do not pay attention to multitasking.

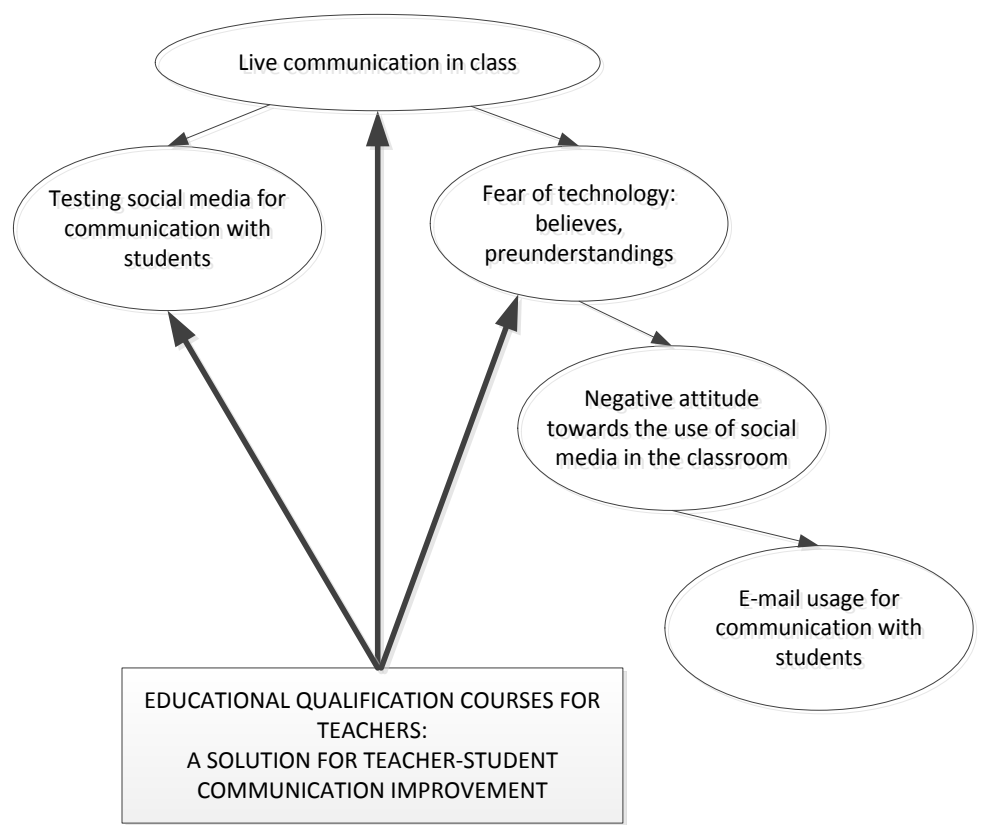

Figure 2. Vocational teachers' communication with students (VET school situation analysis) with solutions for communication improvements

\section{CONCLUSIONS AND DISCUSSION}

The development of competence-based approach (which is used in Lithuanian VET institutions) depends on existing institutional conditions and capacities of vocational education and training provider (the VET school). The most used technology in vocational teaching and rural VET school interactive activities remains practices and laboratory work. Teachers believe, that practical activities correspond to the students' professional experience and the cognitive learning potential. Books, textbooks and printed materials, although still popular, but are less commonly used. The book transformation to online materials is observed. This is in-line with the technology enhanced learning development. In addition, vocational teachers are forced to use reproductive cognitive techniques, because their students lack study motivation and the level of general education is not high.

The growth of smart educational technology influences VET teachers' pedagogical and methodological preparation and practical experience. Two approaches exist - technology-centered and learner-centered (Mayer, 2003). Learner-centered approach, which is followed by our research participants VET teachers, is in-line with Spencer and Jordan (1999) learner centered approaches in medical education and in particular with task based learning, experiential and reflective learning, small group and problem based learning.

Deutscher and Winther (2017) found that teacher-student communication is not an isolated endeavor but rather the combination of curriculum, instruction and assessment. Our findings extended Deutscher and Winther (2017) research and showed that teachers' professional competence, knowledge and skills determines not only students learning outcomes but also social and cultural educational communication. Additionally, we map the vocational teachers' communication with students and provide solutions for improvement.

From the beginning of $21^{\text {st }}$ century, teachers use the smart educational technology to draw attention to each student, help the learner to know himself and his or her field of professional expression (Dawson, 2010). VET teachers in rural schools also use various technologies in class, but contrary to the tradition, only part of teachers communicate and collaborate with the students using various virtual channels.

Lin and $\mathrm{Lu}$ (2011) research proved that the motivation to use technologies grows than adult person find enjoyment in internet peer-communication. Lin and Lu (2011) stated that the number of networked peers is more important than network friends. Our research confirmed that self-motivation to use smart education technology grows then teacher students developed virtual peer-communication. Students motivated teachers to use technologies and vice versa - teachers motivated their students. This was another important issue that we found.

The smart education technology application to teaching at a rural vocational training institution is influenced by three main factors: i) self-motivation to use technologies; ii) mastery in technology; iii) innovative study methods. Both education actors (teachers and students) need to be self-motivated to understand and use the smart educational technology. If only one actor is self-motivated, it is not enough. Mastery in technology is directly related to self-motivation to use technologies. Innovative study methods through self-motivation and mastery in technology help teachers to construct vocational study curricula and additionally motivate their students. 


\section{Proceedings of the $8^{\text {th }}$ International Scientific Conference Rural Development 2017}

Live communication in many classes is augmented with social media. Vocational teachers behave in two ways using social media in class for communication and collaboration. Some teachers test various social media while communicating with their students. Others have negative attitudes to media and prefer different communication channels. If these teachers use internet, they communicate through e-mails. This negative attitude is formed by mass media and discussions with other colleagues and VET teachers. The attitude changes while teacher start to use smart educational technology more actively in class activities. Physical communication in class remains the popular solution for VET teacher-student communication improvement.

\section{Acknowledgment}

This pilot study was done with vocational teachers from rural Lithuanian VET schools. The profession teachers participated in research. Additional research with different participants, such as VET school students or school administration could fruitful the data. A more extended quantitative study could add another flavor. The content analysis of vocational study programmes and study process observation could extend the picture.

\section{REFERENCES}

1. Billett, S., Choy, S. 2013. Learning through work: Emerging perspectives and new challenges. Journal of Workplace LeFarning, Vol. 25, Iss. 4, pp. 264-276. https://doi.org/10.1108/13665621311316447

2. Corbin, J., Strauss, A. 1990. Grounded theory research: Procedures, canons and evaluative criteria. Zeitschrift für Soziologie, Vol. 19, Iss. 6, pp. 418-427. https://doi.org/10.1515/zfsoz-1990-0602

3. Dawson, S. 2010. 'Seeing' the learning community: An exploration of the development of a resource for monitoring online student networking. British Journal of Educational Technology, Vol. 41(5), pp. 736-752. https://doi.org/10.1111/j.14678535.2009.00970.x

4. Deutscher, V., Winther, E. 2017. Instructional sensitivity in vocational education. Learning and Instruction. http://dx.doi.org/10.1016/j.learninstruc.2017.07.004

5. Education at a Glance: OECD Indicators, 2016

6. Hämäläinen, R., Cattaneo, A. 2015. New TEL Environments for Vocational Education-Teacher's Instructional Perspective. Vocations and learning,Vol. 8(2), pp. 135-157. https://doi.org/10.1007/s12186-015-9128-1

7. Harry, B., Sturges, K. M., Klingner, J. K. 2005. Mapping the process: An exemplar of process and challenge in grounded theory analysis. Educational researcher, Vol. 34(2), pp. 3-13. https://doi.org/10.3102/0013189X034002003

8. Keengwe, J., \& Bhargava, M. 2014. Mobile learning and integration of mobile technologies in education. Education and Information Technologies, Vol. 19(4), pp. 737-746. https://doi.org/10.1007/s10639-013-9250-3

9. Lin, K. Y., Lu, H. P. 2011. Why people use social networking sites: An empirical study integrating network externalities and motivation theory. Computers in Human Behavior, Vol. 27(3), pp. 1152-1161. https://doi.org/10.1016/j.chb.2010.12.009

10. Lithuanian education in numbers, 2016. Vocational education: Vilnius, 2016. p. 80

11. Marchand, T.H.J. 2008. Muscles, morals and mind: Craft apprenticeship and the formation of person. British Journal of Education Studies, Vol. 56(3), pp. 245-271.

12. Mayer, R. E. 2003. The promise of multimedia learning: using the same instructional design methods across different media. Learning and Instruction, Vol. 13(2), pp. 125-139.https://doi.org/10.1016/S0959-4752(02)00016-6

13. Merriam, S.B. 1998.Qualitative Research and Case Study Applications in Education. Revised and Expanded from "Case Study Research in Education". Jossey-Bass Publishers, 350 Sansome St, San Francisco, CA 94104.

14. Oliver-Hoyo, M., Allen, D. 2006. The use of triangulation methods in qualitative educational research. Journal of College Science Teaching, Vol. 35(4), pp. 42-47.

15. Schnepf, S.V. 2017. How do Tertiary Dropouts Fare in the Labour Market? A Comparison between EU Countries. Higher Education Quarterly, Vol. 71, pp. 75-96. https://doi.org/10.1111/hequ.12112

16. Shaidullina, A.R., Krylov, D.A., Sadovaya, V.V., Yunusova, G.R., Glebov, S.O., Masalimova, A.R., Korshunova, I.V. 2014. Model of vocational school, high school and manufacture integration in the regional system of professional education. Review of European Studies, Vol. 7(1), pp. 63-67. https://doi.org/10.5539/res.v7n1p63

17. Spencer, J. A., Jordan, R. . 1999) Learner centred approaches in medical education. British Medical Journal, Vol. 318(7193), pp. 1280-1283. https://doi.org/10.1136/bmj.318.7193.1280

18. Stewart, C.M., Schifter, C.C., Selverian, M.E. M. (Eds.). 2010. Teaching and learning with technology: Beyond constructivism. Routledge.

19. Tūtlys, V., Aarna, O. 2017. Competence-based Approach in the Education Reforms of Lithuania and Estonia. Competence-based Vocational and Professional Education (pp. 381-406). Springer International Publishing. https://doi.org/10.1007/978-3-31941713-4_18

20. Yin, R.K. 2013. Case study research: Design and methods. Sage publications. 